\title{
Influence of Brand Equity Towards Perceived Value in 5 Star Hotel at Jakarta
}

\author{
Regina Dewi Hanifah \\ Program Study Hotel Management \\ Bunda Mulia Tourism Academy \\ Jakarta, Indonesia \\ reginadewihanifah@gmail.com
}

\author{
Agustinus Sri Wahyudi \\ Trisakti School of Management \\ Jakarta, Indonesia \\ tinus29@yahoo.com
}

\author{
Nurbaeti \\ Trisakti Institute of Tourism \\ Jakarta, Indonesia \\ nurbaeti@stptrisakti.ac.id
}

\begin{abstract}
The purpose of this study was to examine hotel's brand equity by measuring Aakers four dimensions including brand loyalty, perceived quality, brand awareness and brand association, and to investigate the relationships brand equity and customer perceived value. This research is using quantitative data and using data primer and seconder for this research. The primary data collected from observations, interview and using questionnaire which filled by respondents. The survey was conducted from March - May 2016, with 120 respondents who already stay minimum one time before this stay to measure customer perceived value. The finding of this study showed that the brand equity that has a variable brand awareness, brand association, perceived quality and brand loyalty simultaneously and partially significant effect on Perceived Value guests at 5 star hotels in Jakarta. The most dominant variable towards Perceived Value in this research is the Brand Association.
\end{abstract}

Keywords-Brand Awareness, Brand Association, Perceived Quality, Brand Loyalty, Brand Equity.

\section{INTRODUCTION}

Jakarta as the capital city of Indonesia also become a business centre for Indonesia. That's why to accomodate a businessman/woman to do their trip, Jakarta has a lot of Business Hotel which located in business area, one of them is Bundaran Hotel Indonesia, Centre Jakarta. Many hotels construction in progress to become a new competitor for 5 star hotels. Beside compete with a same star, they need to compete with another category hotels. It caused many 3 and 4 star hotels in Jakarta nowadays having a small meeting room also to served customer from Corporate market segment with a cheaper price than 5 star hotels.

Those condition makes each classification hotel needs to review their performance and give the best impression and choose by their guest. 5 star hotel as the highest classification needs to compete and give a good image instead of price war. (Cobb-Walgren et al. 1995) found that the hotel brand with higher brand equity generated significantly greater preference and purchase intention. Increasing brand equity has become a key objective for firms, which can be achieved through gaining more favorable associations and feelings towards the product or service among target consumers. Hence, measuring brand equity is of great importance to a company's long-term success of future marketing programs since "Perhaps a firm's most valuable asset for improving marketing productivity is the knowledge that has been created about the brand in consumers' minds from the firm's investment in previous marketing programs" (Keller, 2003). Today, brands are recognized as part of a company's capital, which is why they should be exploited and managed. Brands are intangible assets that can create added benefits for the business.

It supported with theory (Aaker, 2002), if company has a good brand equity it will give a good perceived value both to the guest and the company. Brand equity divide into 5 dimensions, they are brand awareness, brand association, perceived quality, brand loyalty and other proprietary assets. With enhancing those 5 dimensions it will enhancing a value to customers also for company itself.

Furthermore, the previous researcher studied the relationship between brand equity and guest value and revisit intention in the mid-priced hotel sector, and found that all dimensions of brand equity (i.e., brand loyalty, perceived quality and brand awareness/association) have a positive effect on perceived value and only two dimensions (brand loyalty and brand awareness/association) were found to significantly influence revisit intention (Kim et al, 2008). In previous study, (Suhartanto, 2011) found that International hotel brands guests in Indonesia perceive better service quality and brand loyalty compared with domestic hotel guests.

Perceived value is a comparison between benefit and sacrifice (Zeithaml, 1988). In those study finding indicates that perceived value of domestic hotels was based on their lower rates (sacrifice) but for international hotel guest, with their higher rates, it was based on psychological benefit. For this customer, prestige as a reflection of status is an important 
factor enhancing their social identity. Perceived value is defined as a trade- off between benefits and sacrifies perceived by customers in suppliers offering. The literature reveals that perceived value research is undertaken mostly on goods, while less so on services, particularly on services related to tourism. Further, most research projects are implemented in developed countries, especially in USA, while much less research is done in Europe. Especially with regard to hotel services, the research mostly neglect perceived value as a critical component of overall hotel guest's perceived service, although single measurement constructs (e.g., quality, satisfaction) are developed (Bolton and Drew, 1991; Woodruff and Gardial, 1996; Cronin et al., 2000; Ekinci and Riley, 2001)

The developing and understanding of brand equity and perceived value, and how these concepts relate to each other really rare and limited in Indonesia as developing country. Based on phenomenon that appear in competition of hotels in Jakarta, especially for business hotel makes the writer want to research why this problem appear and the writer wants to research is implementation of brand equity influence perceived value for guest hotel 5 star hotel in Jakarta. The effect of each other (brand equity and perceived value) never test before and specially in Jakarta as the centre of business in Indonesia. That's why the writer interest to test it on 5 star hotel in Jakarta to know influence of brand equity towards perceived value of the guest. The purpose of this research is to measure brand equity by adopting Aaker's four dimensions of brand equity which are brand loyalty, perceived quality, brand association and brand awareness in international brand hotel located in Bundaran Hotel Indonesia, Jakarta and to investigate the impact of brand equity on customer perceived value in 5 star international brand hotel located in Bundaran Hotel Indonesia, Jakarta as a business centre.

\section{LITERATURE REVIEW}

Conceptualizing brand equity from customer perspective is useful because it suggests both specific guidelines for marketing strategies and tactics and areas where research can be useful in assisting managerial decision making. The source of brand equity is customer perceptions (Keller, 2003) hence it is important for managers to measure and track brand equity at the customer level (Lassar, et al, 1995). The customer based brand equity approach is more practical as the information offers a strategic vision of customer behavior and managers can develop strategies accordingly. Brands facilitate information processing, and interpretationof customer, create trust for consumers in making purchases, and provide consumers with the satisfaction of use (Aaker, 1991). Brands are seen as adding value, to the extent that they also socially qualify the buyer (Kapferer, 2004). It would seem that brands increase the perceived value of products (Mizik and Jacobson, 2009).

Baldauf et al (2003) examined the relationship between the three dimensions of brand equity and perceived value. They argued that loyal customers recognized the favorable benefit opportunity and customers who were familiar with products and logos were more willing to pay price premium. Therefore, they insisted that brand loyalty and brand awareness were positively related to perceived value.
This research considers brand loyalty, brand awareness, perceived quality along with brand associations as the important dimensions of brand equity. Although many researchers agree on the conceptual model of the four components of brand equity, empirical results have not been supportive. In the previous studies (Yoo and Donthu, 2001) they had used student samples to validate the consumer based brand equity scale.

Based on literature review, the different perspectives of brand equity and their methodologies of measurement were discussed. In this research, as method of measuring brand equity, four of the five dimensions of Aaker's brand equity were adopted. He mention that brand equity consists of brand loyalty, brand awareness, perceived quality, brand association and other proprietary brand assets such as patents, trademarks and channel relationship. The writer didn't use the fifth components which not relevant to the consumer perception, only the first four components of brand equity were adopted for this research.

\section{A. Hypothesis}

\section{1) Brand Equity}

Lassar et al. (1995) define perceived value as the perceived brand utility relative to its costs, assessed by the consumer and based simultaneous considerations of what is received and what is given up to receive it. Consumer choice of a brands depends on a perceived balance between the price of a product and all its utilities. A consumer willing to pay premium prices due to the higher brand equity. Baldauf et al (2003) examined the relationship between the three dimensions of brand equity (brand awareness, brand loyalty, and perceived quality) and perceived value. He discovered that loyal customers recognize a favorable benefit opportunity, and customers who are familiar with products and logos willingly pay a price premium. Aaker (1991) defined brand equity from a customer perspective and emphasize that customer based brand equity provides value to the firm and the customers. Based on theory and research above, the writer propose the following hypothesis:

H1: Brand Equity will have a positive influence towards perceived value

Ho: There is no relation and positive influence between brand equity and perceived value.

Ha: There is a relation and positive influence between brand equity and perceived value.

\section{B. Brand Awareness}

Keller (2003) defines awareness as "the customers' ability to recall and recognize the brand as reflected by their ability to identify the brand under different conditions and to link the brand name, logo, symbol, and so forth to certain associations in memory". Brand awareness can be measured as a brand recognition or brand recall, otherwise both of them. According to Monroe and Krishnan (1985) and Dodds et al. (1991), recognizing a brand name or logo can lead to positive customer assessments in terms of considering a product as good value for money or a good bargain. A higher level of brand awareness 
reduces the consideration set. Hence, brand awareness should positively affect perceived value. Based on theory and research above, the writer propose the following hypothesis:

$\mathrm{H} 2$ : Brand Awareness will have a positive effect on customers' perceived value

Ho: There is no relation and positive influence between brand awareness and perceived value

Ha: There is a relation and positive influence between brand awareness and perceived value

\section{Brand Association}

Brand association consist of all brand related thoughts, feelings, perceptions, images, experiences, beliefs, attitudes (Kotler and Keller, 2006) and is anything linked in memory to a brand. Aaker's said that brand association make the customer create a value and decide which product that they will choose. It supported with studies that brand association could help customer to process the information, differentiation product, reason to buy, create a positive feeling, and distribution basis (Rangkuti, 2009), Based on theory and research above, the writer propose the following hypothesis:

H3: Brand Association will have a positive effect on customers' perceived value

Ho: There is no relation and positive influence between brand association and perceived value

Ha: There is a relation and positive influence between brand association and perceived value

\section{Perceived Quality}

Perceived quality is the customer's judgement about a product's overall excellence or superiority that is different from objective quality (Zeithaml, 1988). Objective quality refers to the technical, measurable and verifiable nature of products/services, processes and quality controls. Perceived quality is hence formed to judge the overall quality of a product/service. According to Monroe and Krishnan (1985) and Dodds et al. (1991), perceived quality is positively related to perceived value. A higher perceived quality, for many people is the reason to buy a product, and some would also be willing to pay a price premium. Based on theory and research above, the writer propose the following hypothesis:

H4: Perceived Quality will have a positive effect on customers' perceived value

Ho: There is no relation and positive influence between perceived quality and perceived value

Ha: There is a relation and positive influence between perceived quality and perceived value

\section{E. Brand Loyalty}

Loyalty is a core dimension of brand equity. Aaker (1996) described brand loyalty as "the attachment that a customer has to brand". A strong form attachment refers to the resistance to change and the ability of a brand to withstand bad news. Brand loyalty plays an outstanding role in generating brand equity not only because of its capacity to keep a customer loyal, but also because that customer's loyalty extends to brands in the company's portfolio. Building brand loyalty triggers potential profits for a company. Moreover, loyal customers are more likely to pay price premiums and are less likely to be price sensitive. Loyalty could increase both company and customer value. Loyal customers recognize the favorable benefit/cost opportunity, and brand loyalty should positively impact customer value (Monroe and Krishnan,1985 and Dodds et al.,1991). Based on theory and research above, the writer propose the following hypothesis:

H5: Brand Loyalty will have a positive effect on customers' perceived value

Ho: There is no relation and positive influence between brand loyalty and perceived value

Ha: There is a relation and positive influence between brand loyalty and perceived value.

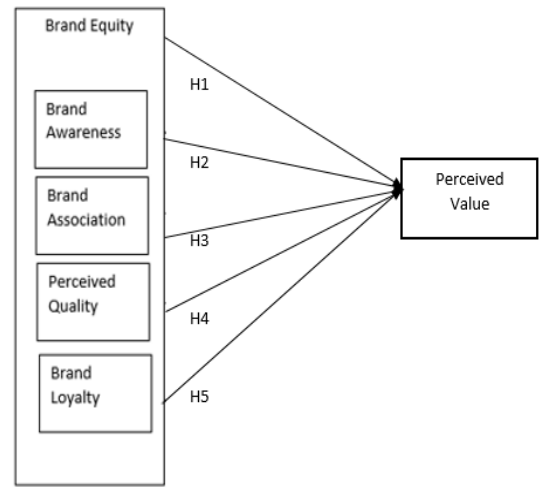

Fig. 1. Hypotehsi

\section{Methods}

The research methodology that used in this research is qualitative descriptive. The writer use likert scale 1-4 to avoid neutral answer in the research because for neutral will not represents about agree or disagree of respondent for the question. The data in questionnaire will describe two main things, demographic data which contain of Gender, Age, Origin of Country, Level Education and Income, and the second things is Indicator of each variable. Population from this research is all guests who already stay in one of 5 Star Hotel in Bundaran Hotel Indonesia Jakarta, Mandarin Oriental Jakarta, Grand Hyatt Jakarta, Pullman Jakarta Thamrin, Hotel Indonesia Kempinski Jakarta dan The Keraton at The Plaza. The respondents were approached by researcher and asked first if they had the experience of visiting one of the 5 hotels in Bundaran Hotel Indonesia Jakarta. The writer will use respondent with criteria below to support this research:

1. Guest who has hotel experience in 5 Star hotel at Bundaran Hotel Indonesia with minimum stay 2 times in the same hotel to measure about their value of brand equity

2. Age $>17$

3. Period stay March-May 2016 
Hair et al. (2010:604) states that the sample size plays an important role in estimating and interpreting research results. The first consideration involves the overall sample size. Many studies suggest a ratio of 20 observations for each predictor variable. The minimum size recommended is five observation per independent variable, and this ratio applies to all variables considered in analysis, even if all of the variables considered are not entered into the discriminant function. Based on those theory, the writer use 30 observation per independent variable and this research has 4 independent variable. The total respondent that writer used are 120 respondents.

The writer use a primary data by questionnaire and interview and for secondary writer using a book reference, internet research and journal to get information about common knowledge regarding Brand Equity and Perceived Value. In order to get the results of research in accordance with the purpose of research, analysis methods are needed to get the correct data. Analysis of the data to test the hypothesis by using multiple regression analysis.

\section{RESULT}

\section{A. Demographic Data}

Characteristic of respondents based on demographic test are the majority of guest are male with 79 guests $(65,83 \%)$ and female only 41 guests $(34,17 \%)$. Based on age, it could shown which age category is the most guest in Bundaran Hotel Indonesia's Hotel. It was devided into 5 big range category start from 17 years old until above 50 years. The youngest guest limited start from 17 years old, which believed that they have their independency in thinking and action. Also in Indonesia people at age 17 already have their identity card. The most category of age in those hotel is range of 34-41 years old at 56 guests $(46,67 \%)$. It means almost half os respondents in this range. The second range is guest in range 26-33 years old at 35 guests $(29,17 \%)$. Followed by guest in range $42-49$ years old at 22 guests $(18,33 \%)$, and guest in range $17-25$ years old at 4 guests $(3,33 \%)$. The last range is guests in range age above 50 years old only 3 guest $(2,50 \%)$. Based on marital status it shown that half of respondents are married at 69 guests $(57,50 \%)$ and the rest guest still single with 51 guests $(42,50 \%)$. The most original country of respondents is Indonesia with 81 guests $(67,50 \%)$, Followed by guest from United Kingdom/Netherland/ Franc/Germany/Russia with 17 guests $(14,17 \%)$, and the third is guest from USA and Canada with 9 guests $(7,50 \%)$, followed by guest from Australia/New Zealand with 6 guests $(5 \%)$, and then guest from Singapore/Malaysia/Philippines/Thailand/Brunei

Darussalam/Vietnam with 3 guests $(2,50 \%)$ and the last is guest from Saudi Arabia/UEA/Iran/South Africa and Japan/Korean/China/Taiwan are only 2 guests $(1,67 \%)$ from those category. Based on data, it shows that 103 guests $(85,83 \%)$ in Bundaran Hotel Indonesia are Bachelor degree. Followed by guests who finished their Diploma with 13 guests $(10,83 \%)$, and the rest are guests who finished their Master Degree with 4 guests $(3,33 \%)$.

\section{B. Measurement Models}

As the variables tested in this study are constructs, analysis of the measurement accuracy of the construct was needed before testing the hypothesis. The measurement analysis was assessed by evaluating the realibility and validity of the constructs. Validity test showed the value of corrected item total correlation for each item is higher than $r$ table. Based on data it shows that all indicator have corelation coefficient higher than r-table $(0,4044)$. Therefore it is concluded that all items are valid to measure perceived value. Based on realibility test above it shows that overall reliability value is 0.945 , with a 24 question items.

Analysis and interpretation of results is based on the results of testing of the hypothesis. The purpose of testing this hypothesis is to reject the null hypothesis $\left(\mathrm{H}_{0}\right)$ that a hypothetical alternative is acceptable. Hypothesis testing is done with a model of data analysis used in this research is multiple regression analysis. Multiple regression analysis was used to analyze the influence of independent variables consisting of Brand Association (X1), Brand Awareness (X2), Perceived Quality (X3), and Brand Loyalty (X4) towards dependent variable Perceived Value (Y). The error tolerance limit used is $5 \%(0,05)$.

Based on table below can be specified multiple regression equation:

$Y=-9,638+0,220 X_{1}+0,413 X_{2}+0,350 X_{3}+0,254 X_{4}$

Multiple linear regression equation is described as follows:

Constansta -9.638 states that if there are no factors Brand Awareness (X1), Brand Association (X2), Perceived Quality (X3), and Brand Loyalty (X4), the Perceived Value is equal to -9.638 .

a. The coefficient of 0.220 , stating that there is an increase or any increase brand awareness factor (X1), for one unit will increase the Perceived Value of 0.220 .

b. The coefficient of 0.413 , stating that there is an increase or improvement of any factor Brand Association (X2), for one unit will increase the Perceived Value of 0.413.

c. The coefficient of 0.350 , stating that there is an increase or improvement of any factors Perceived Quality (X3), for one unit will increase the Perceived Value of 0.350.

d. The coefficient of 0.254 , stating that there is an increase or any increase Brand Loyalty factor (X4), for one unit will increase the Perceived Value of 0.254

e. From four independent variables are used that give dominant influence is variable Brand Association with a regression coefficient of 0.413 .

The coefficient of determination is a parameter to measure how far the ability of models (especially the independent variable) in explaining the variation of the dependent variable. Testing the coefficient of determination used to describe how much the dependent variable variation can be explained by the variation of all the dependent variables. Coefficient determination test observed through the value of adjusted $R^{2}$

To calculate the effect of Brand Equity on Perceived Value in 5-star hotel in Jakarta used numbers R Square (number correlates in squared) or the coefficient of determination. In the 
above table views known coefficient of determination of Adjusted $\mathrm{R}^{2}$ value is 0.581 . This means that $58.1 \%$ of the variation of the dependent variables Perceived Value can be predicted from a combination of all independent variables Brand Equity (Brand Association (X1), Brand Awareness (X2), Perceived Quality (X3), and Brand Loyalty (X4)). While the remaining $41.9 \%$ are all factors that are not included in the research model.

$R$ value in the above table is the correlation coefficient of variables Brand Equity and Perceived Value is equal to 0.772 . Based on the guidelines for the interpretation of the correlation coefficient value by Sarwono (2006) 0.772 is in the range level of relationship / correlation is very strong. It can thus be concluded that between variables Brand Equity and Perceived Value there is influence of a very strong relationship.

1) F-Test

Simultaneous effect of variables brand awareness, brand association, perceived quality and brand loyalty to perceived value can be seen in the table below.

\section{Hypothesis 1}

\section{H1: Brand Equity will have a positive influence towards perceived value}

Ho: There is no relation and positive influence between brand equity and perceived value

Ha: There is a relation and positive influence between brand equity and perceived value

Based on table above that the value of F-Count of all independent variables of 42,334> from F-Table $(2,68)$, then $\mathrm{H} 0$ rejected and $\mathrm{H} 1$ accepted. Means all independent variables (Brand Loyalty, Brand Association, Brand Awareness dan Perceived Quality) has a significance influence simultaneously towards the dependent variable, Perceived Value. This is an accordance with Aaker (1991) defined brand equity from a customer perspective and emphasize that customer based brand equity provides value to the firm and the customers.

\section{2) t-Test}

Partial test is intended to determine whether there is influence of each independent variable on the dependent variable Perceived Value independently. In this study, a partial test performed using the t test.

\section{Hypothesis 2}

Hypothesis 2 tested the effect of Brand Awareness on Perceived Value in which the sound of the null hypothesis and the alternative hypothesis is as follows:

$\mathrm{H}_{0}$ : There is no relation and positive influence between brand awareness and perceived value

$\mathrm{H}_{2}$ : There is a relation and positive influence between brand awareness and perceived value.

Based on the regression results in table previously obtained value t count variable Brand Awareness (2.776) > t table (1.659) then $\mathrm{H} 0$ and $\mathrm{H} 2$ accepted. It means variable Brand Awareness has significant influence / means partial to variable Perceived Value Hotel guests staying at the 5 star Hotel in Jakarta. This is in accordance with the theory from Monroe and Krishnan (1985) and Dodds et al. (1991), recognizing a brand name or logo can lead to positive customer assessments in terms of considering a product as good value for money or a good bargain. It means brand awareness has a positive influence towards perceive value.

\section{Hypothesis 3}

Hypothesis 3 examines the effect on Perceived Value Brand Association where the sound of the null hypothesis and the alternative hypothesis is as follows:

$\mathrm{H}_{0}$ : There is no relation and positive influence between brand association and perceived value $\mathrm{H}_{3}$ : There is a relation and positive influence between brand association and perceived value.

Based on the regression results in table previously obtained value $\mathrm{t}$ count variable Brand Association (6.040)> $\mathrm{t}$ table (1.659) then $\mathrm{H}_{0}$ and $\mathrm{H}_{3}$ is accepted. It means variable Brand Association has a significant influence / means partial to variable Perceived Value Hotel guests staying at the 5 star Hotel in Jakarta. The results is related with theory from Aaker (1996) which stated that brand association make the customer create a value and decide which product that they will choose.

\section{Hypothesis 4}

Hypothesis 4 tested the effect of Perceived Quality on Perceived Value in which the sound of the null hypothesis and the alternative hypothesis is as follows:

$\mathrm{H}_{0}$ : There is no relation and positive influence between perceived quality and perceived value

$\mathrm{H}_{4}$ : There is a relation and positive influence between perceived quality and perceived value.

Based on the regression results in table previously obtained value $\mathrm{t}$ count variable Perceived Quality (4.654)> $\mathrm{t}$ table (1.659) then $\mathrm{H}_{0}$ and $\mathrm{H}_{4}$ is accepted. It means variable Perceived Quality has a significant influence / means partial to variable Perceived Value Hotel guests staying at the 5 star Hotel in Jakarta. This is in accordance with Monroe and Krishnan (1985) and Dodds et al. (1991), that perceived quality is positively related to perceived value. A higher perceived quality, for many people is the reason to buy a product, and some would also be willing to pay a price premium.

\section{Hypothesis 5}

Hypothesis 5 examines the effect Perceived Value Brand Loyalty towards where the sound of the null hypothesis and the alternative hypothesis is as follows:

$\mathrm{H}_{0}$ : There is no relation and positive influence between brand loyalty and perceived value

$\mathrm{H}_{5}$ : There is a relation and positive influence between brand loyalty and perceived value

Based on the regression results in table previously obtained value $t$ count variable Brand Loyalty (3.375)> t table (1.659) then $\mathrm{H}_{0}$ and $\mathrm{H}_{5}$ is accepted. This is means that variable Brand Loyalty has a significant influence / means partial to variable Perceived Value Hotel guests staying at the 5 star Hotel in Jakarta. It was accordance with Aaker (1996) that stated Brand 
loyalty plays an outstanding role in generating brand equity not only because of its capacity to keep a customer loyal, but also because that customer's loyalty extends to brands in the company's portfolio. Loyalty could increase both company and customer value. Loyal customers recognize the favorable benefit/cost opportunity, and brand loyalty should positively impact customer value.

\section{CONCLUSION}

This study conduct in five hotel 5 star in Bundaran Hotel Indonesia Jakarta to research Brand Equity towards Perceived Value from Guest Perspective who already stay in the same hotel previously. Total respondents is 120 guest from five different hotels. From previous chapter it could be concluded that, variable Brand Equity has a significance influence simultaneously towards Perceived Value, variable Brand Awareness has a significance influence towards Perceived Value, variable Brand Association has a significance influence towards Perceived Value, variable Perceived Quality has a significance influence towards Perceived Value, variable Brand Loyalty has a significance influence towards Perceived Value. From four independent variables are used that give dominant influence is variable Brand Association with a regression coefficient of 0.413 .

\section{REFERENCE}

Aaker, D.A.(1991). Managing Brand Equity.The Free Press: New York

Aaker, D.A.(1996). Building Strong Brand. The Free Press: New York

Bailey,R. And Ball, S.(2006).An exploration of the meanings of hotel brand equity. The service Industries Journal, Vol.26 No.1, pp 15-38.

Baldauf, A., Cravens, K.S., \& Binder, G. (2003). Performance Consequences of Brand Equity Management: Evidence from Organization in The Value Chain. Journal of Product \& Brand Management, 12(4), 220-236.

Ballester, E.D. \& Aleman, M.L.(2005). Does brand trust matter to brand equity?.Journal of Product \& Brand Management, 14(3), 187-196.

Bardi, J. (2007).Hotel Front Office Management.Second Edition. Van Nostrand Reinhold: USA

Batra, R., Ramaswamy, V., Alden, D. L., Steenkamp, J. E., \& Ramachander,S. (2000). Effects of Brand Local and Nonlocal Origin on Consumer Attitudes in Developing Countries. Journal of Consumer Psychology,9(2), 8395.

Berry,L.L.(2000).Cultivating Service Brand Equity. Journal of the Academy of Marketing Science, Vol. 28, Winter

Blackston, M. (1995). The Qualitative Dimension of Brand Equity. Journal of Advertising Research, 35(4), RC2RC7.

Buil, I., de Chernatony, L. \& Martinez, E., (2008). A crossnational validation of the consumer-based brand equity scale. Journal of Product \& Brand Management, 17(6), pp. 384-392.

Chen, S., \& Quester, P. (2006). Modeling store loyalty: Perceived value in market orientation practice. The Journal of Services Marketing, 20, 188-204.

Cobb,W.C., Rubble, C., \& Donthu, N.(1995). Brand Equity, Brand Preference, and Purchase Intent. Journal of Advertising, 24(3), 25-40.

Cronin, J. J. Jr., Brady, M. K., \& Hult, G. T. M. (2000). Assessing the effects of quality, value, and customer satisfaction on consumer behavioral intentions in service environments. Journal of Retailing, 76, 193216.

Davis, J.C. (2007). A conceptual view of branding for services. Innovative Marketing, Vol. 3 No. 1, pp. 7-14.

De Chernatony, L., Mc Donald, M.(1989).Creating Powerful Brands in Consumer, Sevrice and Industrial Markets. Oxford: Butterworth-Heinemann.

Dodds, W. B. \& Monroe, K. B.(1985).The effect of brand and price information on subjective product evaluations. Advances in Consumer Research, 12(1), 85-90.

Erdem, T., Swait, J.(1998).Brand equity as a Signaling Phenomenon. Journal of Consumer Psychology, 7(2), 131-157.

Ger, G. (1999). Localizing in the global village: Local firms competing in global markets. California Management Review, 41(4), 64-83.

Ghozali, Imam. (2013).Aplikasi Analisis Multivariate Dengan Program IBM SPSS21.UNDIP: Semarang

Grembler, D. And Brown S.W.(1996).The loyalty ripple effect: appreciating the full value of customers.International Journal of Service Industry Management, 10 (3).

Hair, Joseph F., William C. Black, Barry J Babin, Rolph E. Anderson.(2010). Multivariate Data Analysis. Seventh Edition.Pearson: New Jersey

Heskett, J., Jones, T., Loveman, G., Sasser, W, Jr., \& Schlesinger, L.(1994).Putting the Service-profit Chain to Work. Harvard Business Review, (March-April), 167-174.

Jonathan, Sarwono.(2006). Metode Penelitian Kuantitatif dan Kualitatif. Yogyakarta:Graha Ilmu

Keller, K.L. (1993). Conceptualizing, measuring, and managing customer-based brand equity. Journal of Marketing, 57(1), 1-22.

Kim, W. G., Jin-Sun, B., \& Kim, H. J. (2008). Multidimensional customer based brand equity and its consequences in midpriced hotels. Journal of Hospitality \& Tourism Research, 32, 235-254.

Lassar, W., Mittal, B., \& Sharma, A. (1995). Measuring customer-based brand equity. Journal of Consumer Marketing, 12 (4), 11-19.

Mizik, N., \& Jacobson, R.(2008).The financial value impact of perceptual brand attributes. Journal of Marketing Research, 45 (1), 15-32.

Mizik, N., \& Jacobson, R. (2009).Valuing branded businesses. Journal of Marketing, 73 (6), 137-153.

Mooij, M. (2004). Consumer behaviour and culture: Consequences for global marketing. Thousand Oak: 
Sage.

Nurbaeti., Damanik, Janianton., M. Baiquni., amd Nopirin. (2016). The Competitiveness of Tourism Destination in Jakarta, Indonesia. Journal of Business and Management, 18(7), 30

Picktin, D., Broderick A. (2004). Integrated Marketing Communications. Pearson

Prasad, K., Dev, C.S. (2000). Managing Hotel Brand Equity. Cornell Hotel and Restaurant Administration Quarterly, 41(3), 22-31.

Pura, M. (2005). Linking perceived value and loyalty in location-based mobile services. Managing Service Quality, 15(6), 509-538

Ravald, A., \& Gronroos, C. (1996). The value concept and relationship marketing. European Journal of Marketing, 30(2), 19-30

Sangster, A., Wolton, J. And McKenney, S.(2001).The International Hotel Industry. Corporate Strategies and Global Opportunities, Travel, and Tourism Intelligence: London

Schuiling, I., \& Kapferer, J. (2004). Real differences between local and international brands: Strategic implications for international marketers.Journal of International Marketing, 12(4), 97-112.

Sihite, Richard.(2006).Hotel Management.SIC: Surabaya.

Srivastava, R.K. \& Shocker, A.D.(1991). Brand equity: A perspective on its meaning and measurement report,
No. 91-124, Working Paper Series, Marketing Science Institute Cambridge, MA.

Suhartanto, Dwi.(2011).Hotel Brand of Origin: Do Guests Perceive Service Differences?. Journal of Tourism, Hospitality \&Culinary Arts

Sweeney, J. C., \& Soutar, G. N. (2001). Consumer perceived value: The development of a multiple scale Item. Journal of Retailing, 77 (2)

Thaler, R. (1985). Mental accounting and consumer choice. Marketing Science, 4(3), 199-214.

Treacy, M., Wiersema, F. (1993). Customer intimacy and other value disciplines. Harvard Business Review, 71(1), 8493.

Walker, John R.(2008). Introduction to Hospitality. Fifth Edition. Prentice Hall: USA

Woodruff, R. (1997). Customer value: The next source for competitive advantage. 25 (2).

Zeithaml, V. A. (1988). Consumer perceptions of price, quality, and value: A means-end model and synthesis of evidence. Journal of Marketing, 52(3), 2-22.

http://icraindonesia.com/uploaded/ICRA\%20Indonesia\%20Co mmentary-TourismLeisure-131213.pdf

http://businessindonesia.com/june2014 